\title{
Impact of Macroeconomic Factors on Stock Returns of KSE 100 Index
}

\author{
MUHAMMAD TAHIR KHAN \\ Lecturer, Institute of Business Studies and Leadership \\ Abdul Wali Khan University, Mardan \\ ASAF KHAN \\ Lecturer, Institute of Business Studies and Leadership \\ Abdul Wali Khan University, Mardan \\ DR. ADNAN AHMAD \\ Assistant Professor, Institute of Business Studies and Leadership \\ Abdul Wali Khan University, Mardan \\ OBAID ULLAH BASHIR \\ Lecturer, Shaheed Rashid Hussain, Campus, Pabbi \\ Abdul Wali Khan University, Mardan
}

\begin{abstract}
Positive moment of stock return is an important component for investors, the intension of this study was to examine the impact of macroeconomic variables on stock return. The monthly stocks price data of 15 firms was taken from the period of January 2008 to December 2012. The results revealed that there was a positive impact of exchange rate on stock return, while inflation rate and interest rate had a significant negative impact on stock return. The results of variance decompositions revealed that out of three macroeconomic variables Inflation rate showed greater forecast error for KSE 100 Index.
\end{abstract}

Keywords: Stock Return; Exchange rate; Interest rate; Inflation rate

\section{Introduction}

1.1. Background

For companies important source to raise money is investing in stock markets. Stock market allows businesses to be publicly traded or selling shares of company owner ship will raise financial capital in a public market. The liquidity gives the investor ability to easily and quickly sell the securities. This is an attractive feature of investing in stocks, as compared to other less liquid investments. Investors increased Liquidity by trading in their own shares of companies. Whole economic environment is complete picture of the macro economy. To achieve its potential there are some factors necessary to be taken. These are inflation, interest rate, exchange rate, increase agricultural productivity, raise educational achievement, increase quality and quantity of universities, improve infrastructure and improve governance. Macro economy studies the economy as a whole and macro economy controls by variables. To control and stabilize the economy by 
policy of government, that is to reduce fluctuations in the economy. The stock returns increase or decrease occurs due to combination of domestic and global macro economic factors. Macro economic factors such as interest rate, inflation and exchange rate are responsible for the variation in stock returns. Macroeconomic variables like inflation, interest rate and exchange rate play an important role in the economic performance of any country.

Stock returns predict by helping macroeconomic variables, there are many factors like political news, corporate earning that can cause market up and down but economic factors like inflation, GDP, interest rate and exchange rate have the most influence on the long term market performance. In 2009 Chang and Liang used GARCH model to study the impact of macroeconomic variables on stock returns and concluded that macro economic factors can affect stock returns and the influence of macroeconomic factors on stock returns and their variation is not constant. Nelson (1976) using data of monthly stock returns and inflation of US from 1953 to 1974 of the post war and draw a conclusion that there is a negative relationship between stock returns and expected and unexpected inflation.

Chen (1991) find that future stock returns could be predicted by interpreting macroeconomic variables. Bailey and Chung (1996) investigate the impact of macroeconomic risk on stock returns and find that there is a negative relationship between exchange rate and stock returns. John K. M. Kuwornu using monthly data from January 1992 to December, 2008 to examine the relationship between macroeconomic variables such as interest rate, inflation and exchange rate and stock returns and find that there is negative relationship between interest rate, inflation, exchange rate and stock returns. In this paper we have macroeconomic variables as independent variables and stock return is dependent. The hypothesis is based on that there is a significant relationship between stock returns and selected macro economic variables. The method used in this paper is pool regression to estimate the dependent variable. Our goal is to find that how monthly interest, inflation and exchange rate impact stock returns of Karachi stock exchange of 100 index. We have taken a sample of 15 firms and their stock returns were calculated.

\subsection{Research Question}

Is macroeconomic factors effect the stock exchange Performance?

\subsection{Objective of the research}

The main objective of the research is to investigate the impact of macroeconomic factors on the stock returns of KSE 100 index.

\subsection{Scope of the research}

The study is confined to the examine the effect of macroeconomic variables like inflation, Interest rates and Exchange rates on stock returns of KSE 100 index.

\subsection{Significance of the research}

The paper would significantly help the investment decision makers that which assets portfolio to chose to minimize their systematic risk by forecasting inflation, interest rate and exchange rate.

\section{Literature Review}

In the previous decade estimation and analysis of financial risk has been taken greatly. The prediction and evaluation of systematic risk like inflation, interest rate and exchange 
rate is the most important in the area of financial research (Bentz \& Connor, 1998; Brooks et al. 1998). The standard empirical testing of the CAPM suggests that systematic risk of risky asset or portfolio is constant the experimental evidence showed that constant systematic risk is incorrect and not significant to the result that may show incorrect decision. Many statistical techniques have been developed to estimate systematic risk (Cvitanic \& Karatzas, 1999; Gibbons \& Ferson, 1985; Sunder, 1980).it is proof from the paper that there are macroeconomic factors and microeconomic factors that are responsible for the variation in stock returns. Operational changes and changes in business environment are some microeconomic factors and inflation interest rate and exchange rate, market conditions and some relevant future events are some macroeconomic variables (Boss \& Newbold, 1984).

Fabozzi and Francis (1978) suppose that systematic risk of stock may fluctuate randomly rather than remain constant. Nai_fu chen, (1986) Concluded in his research paper that some macro economic variables affect stock returns systematically and some events affect more than the others it depends on investors to diversify the risk but systematic risk cannot be diversify and it will affect stock returns and that no extra reward can be earned by diversifiable risk. Menike (2006) Studied the impact of macroeconomic factors on stock returns taken data from September 1991 to December 2002 from Colombo stock exchange by using multivariate regression was run and concluded that inflation and exchange rate react negatively on stock returns in Sri Lankan stock market. The relationship between exchange rate and stock returns studied by theoretical approaches (Granger, 2000).The firm foreign operation will change when ever exchange rate is changed which will give some profit or loss in short this approach shows that stock returns changed by exchange rate. Quadir (2012) Concluded in his research using Autoregressive Integrated Moving Average (ARIMA) model from the year January 2000 to February 2007 on the basis of monthly time series data that interest rate effect stock returns. (Chen et al, 1986; Mukherjee \& sNaka, 1995; Mayasmi \& Koh, 2000; Kown \& Shin, 1999; Cheung and Ng, 1998; Gjerde \& Saettem, 1999) these practitioners and economist have study the relationship between macroeconomic factors and stock returns over the last few decades.

It is supposed that stock return is determined by the number of fundamental macroeconomic variables like interest rate and inflation rate. Ross (1976) developed arbitrage pricing theory in which he concluded that multiple risk factors can describe stock returns. Chen et al., (1986) concluded in his research which was conducted on US stock market and find that inflation rate is negatively related to stock returns. Mukherjee and Naka (1995) used Vector Error Correction Model and find that macroeconomic variables like exchange rate, inflation rate, money supply, industrial production are responsible for the variation of stock returns. Filis (2008) Examines in his paper that in Greece there is macroeconomic variables and stock return relationship exist by the use of vector error correction model. (Castanias, 1979; Hardouvelis, 1988; Ross, 1989) accept the argument that stock market returns are influenced by macroeconomic variables. Moreover authors like Levine and Zervos (1996), Hooker (2004) and Chiarella and Gao (2004) have proved that stock returns are influenced by macroeconomic variables like interest rate, GDP, productivity and employment. Additionally, authors such as Jones and Kaul (1996), Haung et al. (1996) and Sadorsky (1999) showed that there are other 
variables like oil price that are also important factor for changes occurs in stock return. Retained earnings reinvesting which we obtained and attracting new investment our capital expenditure will be high, it will increase our economic growth and performance of stock market will be good(Ritter, 2005). We concluded that there exist a unidirectional relationship between stock market performance and economic performance.

Flannery and Protopapadakis,(2002) have indentified in his research that macroeconomic variables like inflation rate and exchange rate has explanatory power over stock returns. (Pearce and Roley, 1983; Gjerde and Sættem, 1999; Omrana(2003) studied in his paper that there exist a negative relationship between inflation and interest rate with stock market performance. This means that higher inflation and interest rate, the lower stock returns and vice versa.(Jaffe \& Mandelker, 1976; Fama \& Schwert, 1977; Fama, 1981; Geske \& Roll, 1983; Chen et al., 1986; Wahlroos \& Berglund, 1986; Cozier \& Rahman, 1988; Lee, 1992; Solnik \& Solnik, 1997; Siklos and Kwok, 1999; Schotman and Schweitzer, 2000; Engsted and Tanggaard, 2002; Kim \& In, 2005) similar findings has been developed by these authors in early 1970 that there exist an inverse relationship between inflation and stock market returns. (Glen, 2002; Bilson et al., 2001; Ritter, 2005) GDP is another variable play an important role in stock market return variation shows that there is positive relationship between GDP and stock returns it means that if GDP increase occurs stock returns also increase. Gjerde and Sættem (1999) concluded in his research which is based on several countries such as(Austrialia, Canada, Norway and Sweden) using VAR approach and proved that there is positive relationship between real activity and stock returns. On the other hand, they pointed out that stock market response to changes in GDP is delayed. Errunza and Hogan (1998) they have been used a VAR model and concluded that European stock returns from 1959-1993 changed by money supply and industrial production. But no effect sees in all European country such as swizerland, U.S, and Belgium.

Relationship in the same direction is not always exist (Balke \& Wohar, 2001; Rapach, 2001). (Carlstrom et al., 2002; Wongbangpo and Sharma, 2002) says that there is no clear relationship exist between macroeconomic variables and stock returns. Schwert (1989) in the period of 1859-1987 he studied the relationship between inflation and stock returns. Predicting future macroeconomic variables volatility can help in finding stock returns volatility. Dritsaki (2005) concluded in his research and argue that inflation and interest rate influence stock returns in Greek by using Johansen co integration approach. Additionally The ophano and Sunil (2006) recommended that there is negative impact of inflation on stock returns by using bivariate VAR models. Tweneboah studied the impact of macroeconomic variables on stock returns by the using the data of bank stock index for the years of 1991 to 2006 using Johansen's multivariate co integration test and innovation accounting techniques. There result shows that interest rate is the key factor of stock return variation. (Humpe and Macmillan, 2007) in different time horizon and in different stock markets the relationship between stock returns and macroeconomic variables has been studied. Also examine the relationship between macroeconomic variables and stock return in two countries such as US and Japan by using co integration analysis they proved that industrial production has positive influence on stock markets and negatively effect by inflation and long run interest rate. 
Humpe and Macmillan (2007) when inflation is high policy maker require tight monetary policy to control inflation this will decrease money supply and increase interest rate which influence discount rate and cost of capital hence negative effect. An increase interest would attract investor to acquire high rate of return due to opportunity cost of investing in shares. The risk of foreign exchange exposure continues to hinder emerging markets' effort to attract foreign investors. The exchange rate exposure does not only threat their cash flows but also reduce their competitive advantage in the market. Adler and Dumas (1984) exchange risk are those risks due to which all the firms input and output prices are influenced by fluctuation in currency. Some authors argued that when the value of home currency decreased price of stock should be increased because of increase in export and decrease in import due to this increase or decrease in export and import our stock return will be fluctuate. Such impact will be finding out by the relative dominance of import and export sectors of the economy. Thus there is a negative relationship between inflation interest rate and exchange rate.

Attari (2013)concluded in his research which was conducted in both the developing and developed countries by applying the Exponential Generalized Autoregressive Conditional Heteroskedasticity (EGARCH) taken monthly data for variables from December 1991 to August 2012 to study the analysis .macro economic variables are inflation interest rate and GDP For representation of stock market, Karachi Stock Exchange (KSE-100 Index) is taken as test market. To check homoskedasticity ADF and ARCH tests are used. The results show that macroeconomic variables have substantial influence on the stock prices. Additionally Pakistani stock market is highly volatile to reduce the volatility policy makers need to pay more serious attention. The key objective of a stock market is to facilitate the savers and the borrowers, as it collects the savings from different pools and provide the platform to convert them into fruitful investment. The macro economic variables has an important element in determining the stocks available in stock markets .To manage their portfolio investors always want to know about the variables that has significant impact on stock returns. Karachi Stock Exchange (KSE) is established in 1947 and KSE 100 index was launched in 1991 consists of top 100 companies which are picked on the basis of capitalization. The macroeconomic variables have much influence on a stock market. There are many global events and policies, followed by the developing countries along with their domestic variables cause the negative influence on market. In recent past, the industry and KSE changed rapidly and hence, affected the economic conditions of Pakistan. (Attari, 2013).

Bollerslev (1986) concluded in his research which was conducted on north Holland using $\mathrm{ARCH}$ and GARCH methodology to measure the inflation rate. Maysami and Koh (2000)analyized stock market of Singapore and the result shows that Singapore market is sensitive due to interest rate and exchange rate. Shrestha(2008) found that the long relation exists among stock prices and the macro factors in China stock market.Jiranyakul (2009) there exists a long-run relationship between the stock market index and a set of macroeconomic variables such as effective exchange rate significantly impose a positive impact on stock returns by showing johansen co integration test shows that variables are co integrated in Thailand. Fama (1981) shows that that there is negative correlation between inflation and stock returns. Chen, Roll and Ross (1986) study the relationship between macro economic variables which include inflation interest rate and exchange 
rate with stock market return by applying a multivariate arbitrage pricing theory (APT) and reach to the conclusion that there is strong relationship between stock returns and these variables. Hamao (1988) in stock market risk premium changed by prediction of inflation in Japanese market so it shows that inflation has a significant effect on stock returns. On the other side Fung and Lie (1990) shows that in Korea stock market response was weak by change in domestic production and money supply. Dhakal, Kandil, and Sharma (1993) to study the impact of money supply on stock return in US test vector auto regression (VAR) model and reach to the conclusion that there is a significant relationship exist between money supply and stock returns. Abdullah and Haywarth (1993) variation in inflation is responsible for change in stock returns and conclude that there is negative correlation between inflation and stock returns.

(CAPM) of Sharp (1964), Linter (1965) and Mossin (1966) suggested stock return is generated by one factor model, market portfolio of risky asset represent these factors model and show that systematic and unsystematic risk are constant. Ross (1976) developed Arbitrage pricing theory, suggested that systematic risk like inflation, interest rate and exchange rate cannot be diversifiable according to arbitrage pricing theory these systematic risk influence stock returns. Stock return is not affected by only one factor model because it is a linear function it include a set of variables. (Özlen and Ergun, 2012) concluded in his research which has been selected 45 componies out of 11 sectors and applying Autoregressive distributed lag method to investigate the effect of selected macroeconomic variables including inflation rate, exchange rate, interest rate, on stock returns, it has been observed that exchange rate, interest rate are highly significant determinant of stock returns movement. (Maysami ,Howe and Hamzah,2004) conducted a research in singa pore and find that there exist a cointegration relation ship between stock return and interest rate,exchange rate and inflation. Fama and Schwert (1977), Nelson(1977), and Jaffe and Mandelker (1976) we can predict stock returns by macro economic variables for nearly 30 years.

Parmar (2013) in any country economic performace depond on inflation,macroeconomic variables help in predicting stock returns draw a conclusion by efficient market theory. In 2009 Chang and Liang GJR-GARCH used to analyze the effect of interest rate on the movement of stock return. (Zafar ET al, 2008) increase in interest rate leading to reduce investment in stock and to choose saving banks to secure their money. As when interest rate comes down investors with draw money from banks and invest in stock, so there exist a negative relationship between interest rate and stock return. Kim (2003) stock prices have a negative relationship between inflation, interest rate and exchange rate. Mohammad et al. (2009) study the relationship of interest rate and stock returns and show that there is negative relationship between interest rate ant stock returns. Exchange rate movement occurs changes in stock return, demand of product, input price, outprice of country influenced by the currency movement, the return of stock will be negatively related the home currency (Donnelly and Sheehy 1996).

Chen et al, (1986), (2005); Fama and French, (1988), Bulmash and Trivoli, (1991); Hooker, (2004); Gjerde et al. (1999); Bilson et al. (2001); Asprem, (1989); Wasserfallen, (1989); Fama, (1981); Abdullah and Hayworth, (1993).they have find out the determinants of stock returns and concluded in his research paper that there is strong relationship exist between macroeconomic variables and stock returns in developed as 
well as Emerging stock markets . In keeping view the question is macroeconomic factors effect the stock exchange Performance? Our hypotheses is:

H1: There is no significant relationship between macroeconomic variables and stock

\section{Methodology}

\subsection{Sample}

The sample taken for this study was 15 companies of 100 KSE-index. The monthly stocks Prices data of 15 firms are implied in the empirical investigation. The systematic sampling technique is used to collect the data from the period of January 2008 to December 2012, five years data was taken for this research.

\subsection{Model Selection}

Many variables include in this paper that has to be studied and their impact should be considered.So for this purpose we use Regression analysis (OLS).It provides the base to deal with the comparison of more variables.By using this model we should not use the dummy variables. The pooled OLS model is written as

$Y_{i t}=X_{i t} \beta+U_{i t}$

Where $Y_{i t}$ is the dependent variable for a unit $i$ in time period of $t . X_{i t}$ is the independent variable that is observed for a unit $i$ in time period $t$. $\beta$ is the systematic risk that is a parameter $U_{i t}$ is the error or disturbance for unit $i$ in time period $t$.

\subsubsection{Regression Model}

Stock Return $=\beta_{0}+\beta_{1} \mathrm{INT}+\beta_{2} \mathrm{INF}+\beta_{3} \mathrm{ER}$

Where:

$\mathrm{SR}=$ stock returns

$\mathrm{INT}=$ Interest rates

$\mathrm{INF}=$ Inflation

$\mathrm{ER}=$ Exchange Rate

\subsection{Dimension of Study Variables}

\subsubsection{Stock Returns}

In this study my dependent variable is stock returns. Stock Returns are the earnings that the shareholders generate from stock trading. This return could be in the form of dividends given by the company to its shareholders from time-to-time or profit through stock trading. Stock returns can be calculated by the following formula.

Stock Return $=\frac{\left(\mathrm{P}_{1}+\mathrm{P}_{0}\right)+\mathrm{D}}{\mathrm{P}_{0}}$

$\mathrm{P}_{1}=$ Current Price of stock

$\mathrm{P}_{0}=$ Previous Price of stock

$\mathrm{D}=$ Dividends

\subsubsection{Inflation}

When purchasing power of money decrease or Real value of money decreases. We will buy few goods than before with the same monitory units whenever there is increase in general price of goods the value of money decreases which result in decreasing the purchasing power. 


\subsubsection{Exchange Rate}

The rate at which currency is exchanged with another currency.. Due to this value of country's currency the money traders operating in the market quote their buying and selling rates and the supply and demand forces that changes it from time to time.

\subsubsection{Interest Rate}

The rate at which the lender receives money from the borrower for using his/her money. The interest rate represents the percentage of the principal to be paid periodically, normally a year or six months. It is also known as borrowing cost of the money.

\section{Empirical Analysis}

In this section we accomplish the empirical investigation to study the association between dependent variables that is stock return and independent variables that are inflation, interest and exchange rate. The hypothesis is to study the impact of macroeconomic variables on stock returns. Monthly stock returns of 15 companies have been taken from January 2008 to 2012. After that OLS model was chosen to run through the data and their estimation were noted. We have estimated the coefficient, $t$-value and p-value.it is shown in the following tables.

\subsection{Interpretation of Inflation Rate}

The table 1 is based on hypothesis in which we have taken stock returns of 15 firms and its relation with macroeconomic variable like inflation is compared. The empirical result shows that there is a significant relationship between inflation rate and stock returns because its $\mathrm{p}$-value is 0.00067 which is less than 0.05.The value of its Inflation coefficient $\mathrm{i}$-e -0.113294 tell us that there is negative relationship between inflation and stock returns which means that if $1 \%$ increase inflation rate will decrease stock returns by $11.3294 \%$ and vice versa.

\section{Table 1: Inflation Rate}

\begin{tabular}{lll}
\hline Companies & Inflation Coefficient & \\
\hline Included 15 & cross & -0.113294 \\
sectional units & & \\
& \\
(t-ratio) & -3.4155 \\
(p-value) & 0.00067
\end{tabular}

\subsection{Interpretation of Interest Rate}

In table 2 we found that there is significant relationship between Interest rate and stock returns (as $\mathrm{p}$ value is equal to 0.00273 which is less than 0.05). The interest rate coefficient is -0.214283 which means that there is inverse relationship between interest rate and stock returns and shows that $1 \%$ change in interest rate will bring $21.4283 \%$ inverse change in stock returns. So there is also impact of interest rate on stock returns. 
Table 2: Interest Rate Coefficient

\begin{tabular}{ll}
\hline Companies & Interest Rate coefficient \\
\hline $\begin{array}{l}\text { Included } 15 \text { cross sectional } \\
\text { units }\end{array}$ & -0.214283 \\
& \\
(t-ratio) & -3.0051 \\
(p-value) & 0.00273
\end{tabular}

\subsection{Interpretation of Exchange Rate}

In table 4.3 taking the other variable that is Exchange rate we conclude from the value given in table 4.3 is that there is a significant relationship between Exchange rate and stock returns.(as p value is equal to the 0.0004 which is less than 0.05 means that there is significant relationship). Although the value of Exchange coefficient is 0.00246728 which means that there is positive relationship between Exchange rate and stock returns. Table 4.3 shows that if 1\% change in Exchange rate will bring $0.246728 \%$ change in stock returns. As there is direct relationship between Exchange rate and stock returns.

\section{Table 3: Exchange Rate Coefficient}

\begin{tabular}{|c|c|}
\hline Companies & Exchange rate coefficient \\
\hline $\begin{array}{l}\text { Included } 15 \text { cross sectional } \\
\text { units }\end{array}$ & 0.00246728 \\
\hline (t-ratio) & 4.1251 \\
\hline (p-value) & \\
\hline
\end{tabular}

\section{Discussion and Conclusion}

\subsection{Discussion}

There is one thing common in Literature review and monthly based data analysis that there is an impact of macroeconomic variables on stocks returns. The impact may be increase or decrease depends on the type of stocks and companies. In most of cases the result shows that impact is negatively related or there is indirect relationship between the dependent and independent variables. The value of dependent variables decrease by increase in independent variables. Some companies' dependent variables have direct or positive relationship with selected macroeconomic variables. These analyses show that the macroeconomic variables have great influence on stock returns. For some companies this influence may cause negative impact while in some cases some companies will get benefit looking at the nature of industry. The Inflation rate, Interest rate and Exchange rate affect most companies but the affect of Interest rate was a little more.

Now coming to the results of hypothesis. The hypothesis of this paper is that " H1:There is a significant relationship between macroeconomic factors and stock returns".From the above analysis and discussion we conclude that yes there is a significant relationship of macroeconomic factors and stock returns. Study the values of three tables above we 
conclude that there is a significant relationship and this significant has affected the coefficient to very much extant. So the hypothesis is true is here.

\subsection{Conclusion}

In this study the analyses the association between dependent variables that is stock return and independent variables that are inflation, interest and exchange rate. Monthly stock returns of 15 companies have been taken from January 2008 to 2012, and the rest data has been taken from other website. The result shows that the macroeconomic variables have a great influence on the stock returns. From the analysis we concluded that all the companies of Karachi stock exchange will be affected by variation in macroeconomic factors. The increase in macroeconomic factors may cause decrease in company stock returns.

\subsection{Recommendations}

The Recommendation of this paper is discussed below

i. We have used Regression analysis method in this paper. Some other testing method like Exponential Generalized Autogressive conditional (EGARCH), Multivariate co integration test, ANOVA test, Multiple linear mode or some other model should be applied.

ii. We have taken only three macroeconomic variables like Inflation, Interest and Exchange rate as independent variables, GDP, FDI, GNP we can also take these variables.

iii. This paper is limited to KSE 100 index. We can take multinational firms to study this paper and analyze its data and study its impact not only on local companies but on international companies so that the scope of research will be increase.

\section{References}

Irfan, M., Attari, J. (2013). The Relationship between Macroeconomic Volatility and the Stock Market Volatility: Empirical Evidence from Pakistan. Pakistan Journal of Commerce and Social Sciences, Vol. 7, 12.

Şerife Özlen, U. E. (2012). Macroeconomic Factors and Stock Returns. International Journal of Academic Research in Business and Social Sciences, Vol. 2, No. 9, 29.

Jecheche, P. (n.d.). An Empirical Investigation of Arbitrage Pricing Theory: A case. Research in Business and Economics Journal, 14.

Ramin C. M. L. C. (2004). Relationship between Macroeconomic Variables and Stock Market Indices: Cointegration Evidence from Stock Exchange of Singapore's All-S Sector Indices. Jurnal Pengurusan, 24, 47.

Agrawalla, R. K. (2005). Share Prices and Macroeconomic Variables in India. 20.

Quadir, M. M. (2012). The Effect of Macroeconomic Variables On Stock Returns on Dhaka Stock Exchange. International Journal of Economics and Financial Issues, Vol. 2, No. 4, 8.

Parmar, D. C. (2013). Empirical Relationship among Various Macroeconomics Variables on Indian Stock Market. International Journal of Advance Research in Computer Science and Management Studies, Volume 1 (Issue 6,). 
Nazir, M. S. (2010). Post Liberalization Impact of Macroeconomic Factors on the Stock Market Returns. Interdisciplinary Journal Ofcontemporaryresearch In Business, Vol 1, No 12, 10.

Hosseini, S. M. Z. A. (2011). The Role of Macroeconomic Variables on Stock Market Index in China and India. International Journal of Economics and Finance, Vol. $3(6), 11$.

Haider, J. I. (2005). Arbitrage Pricing Theory Evidence From An Emerging Stock Market. The Lahore Journal of Economics, 10, 17.

Yin-Wong Cheung, L. K. (1997). International evidence on the stock market and aggregate economic activity. Journal of Empirical Finance 5(1998) 281-296, 16.

Filis, G. (2008). Macro economy, stock market and oil prices: Do meaningful relationships exist among their cyclical fluctuations. p. 40.

Muhammad Mubashir Hussain, M. A. (2012). The Impact of Macroeconomic Variables on Stock Prices An Empirical Analysis of Karachi Stock Exchange. Mediterranean Journal of Social Sciences, Vol. 3 (3), 18.

Erdugan, R. (2012). The Effect of Economic Factors on the Performance of the Australian Stock Market. p. 301.

Jiranyakul, K. (2009). Economic Forces and the Thai Stock Market, 1993-2007. NIDA Economic Review, Vol. 4, No. 2, 12.

Nai-fu chen, R. R. (1986). Economic forces and stock market. journal of business, 59, 22.

Menike, L. (2006). The Effect of Macroeconomic Variables on Stock Prices in Emerging Sri Lankan Stock Market. Sabaragamuwa University Journal, vol 6, 18.

Yasar Köse, M. D. (2010). On the causality between stock prices and exchange rates: evidence from Turkish financial market. Problems and Perspectives in Management, Volume 8, (Issue 1), 17.

McGraw-Hill, T. (2004). Gujarati: Basic Econometrics, (FOURTH EDITION ed.).

Fama, E. F. (1990). Stock Returns, Expected Returns, and Real Activity. The Journal of Finance, Vol. 45, 21. 


\section{Annexure}

The monthly analysis of macroeconomic variables and stock returns is presented here of 15 firms.

Model 3: Pooled OLS, using 900 observations

Included 15 cross-sectional units

Time-series length $=60$

Dependent variable: SR

Robust (HAC) standard errors

$\begin{array}{lccccc} & \text { Coefficient } & \text { Std. Error } & \text { t-ratio } & p \text {-value } & \\ \text { Const } & 0.058296 & 0.0187346 & 3.1117 & 0.00192 & * * * \\ \text { INFRate } & -0.113294 & 0.0331707 & -3.4155 & 0.00067 & * * * \\ \text { Mean dependent var } & -0.010531 & \text { S.D. dependent var } & 0.173233 \\ \text { Sum squared resid } & 26.44010 & \text { S.E. of regression } & 0.171591 \\ \text { R-squared } & 0.019964 & \text { Adjusted R-squared } & 0.018873 \\ \text { F(1, 898) } & 18.29283 & \text { P-value(F) } & 0.000021 \\ \text { Log-likelihood } & 310.3361 & \text { Akaike criterion } & -616.6723 \\ \text { Schwarz criterion } & -607.0675 & \text { Hannan-Quinn } & -613.0032 \\ \text { Rho } & -0.046625 & \text { Durbin-Watson } & 2.083945\end{array}$

Model 4: Pooled OLS, using 900 observations Included 15 cross-sectional units

Time-series length $=60$

Dependent variable: SR

$\begin{array}{lllllll} & 04 / / 7 \text { Coefficient } & \text { Std. Error } & \text { t-ratio } & \text { p-value } & \\ \text { Const } & 0.106954 & 0.0395154 & 2.7066 & 0.00693 & * * * \\ \text { INTRate } & -0.214283 & 0.0713061 & -3.0051 & 0.00273 & * * *\end{array}$

$\begin{array}{llll}\text { Mean dependent var } & -0.010531 \quad \text { S.D. dependent var } & 0.173233\end{array}$

$\begin{array}{llll}\text { Sum squared resid } & 26.71009 & \text { S.E. of regression } & 0.172464\end{array}$

R-squared $\quad 0.009956$

Adjusted R-squared $\quad 0.008854$

$\mathrm{F}(1,898) \quad 9.030706$

P-value(F)

0.002729

Log-likelihood

305.7643

Schwarz criterion $\quad-597.9237$

Akaike criterion

$-607.5285$

Rho

$-0.053367$

Hannan-Quinn

$-603.8594$

Durbin-Watson

2.097662 
Model 5: Pooled OLS, using 900 observations

Included 15 cross-sectional units

Time-series length $=60$

Dependent variable: SR

$\begin{array}{llllll} & \text { Coefficient } & \text { Std. Error } & \text { t-ratio } & p \text {-value } & \\ \text { Const } & -0.207709 & 0.0481412 & -4.3146 & 0.00002 & * * * \\ \text { EXCRate } & 0.00246728 & 0.000598119 & 4.1251 & 0.00004 & * * *\end{array}$

$\begin{array}{lclc}\text { Mean dependent var } & -0.010531 & \text { S.D. dependent var } & 0.173233 \\ \text { Sum squared resid } & 26.47699 & \text { S.E. of regression } & 0.171710 \\ \text { R-squared } & 0.018597 & \text { Adjusted R-squared } & 0.017504 \\ \text { F(1, 898) } & 17.01624 & \text { P-value(F) } & 0.000041 \\ \text { Log-likelihood } & 309.7087 & \text { Akaike criterion } & -615.4175 \\ \text { Schwarz criterion } & -605.8127 & \text { Hannan-Quinn } & -611.7484 \\ \text { Rho } & -0.047969 & \text { Durbin-Watson } & 2.086293\end{array}$

